\title{
Frost flower chemical signature in winter snow on Vestfonna ice cap, Nordaustlandet, Svalbard
}

\author{
E. Beaudon ${ }^{1}$ and J. Moore ${ }^{1,2,3}$ \\ ${ }^{1}$ Arctic Centre, University of Lapland, P.O. Box 122, 96101 Rovaniemi, Finland \\ ${ }^{2}$ Thule Institute, University of Oulu, Finland \\ ${ }^{3}$ College of Global Change and Earth System Science Beijing Normal University, 19 Xinjiekou Wai Street, \\ Beijing, 100875 China
}

Received: 17 November 2008 - Published in The Cryosphere Discuss.: 2 February 2009

Revised: 18 June 2009 - Accepted: 18 June 2009 - Published: 2 July 2009

\begin{abstract}
The chemistry of snow and ice cores from Svalbard is influenced by variations in local sea ice margin and distance to open water. Snow pits sampled at two summits of Vestfonna ice cap (Nordaustlandet, Svalbard), exhibit spatially heterogeneous soluble ions concentrations despite similar accumulation rates, reflecting the importance of smallscale weather patterns on this island ice cap. The snow pack on the western summit shows higher average values of marine ions and a winter snow layer that is relatively depleted in sulphate. One part of the winter snow pack exhibits a $\left[\mathrm{SO}_{4}^{2-} / \mathrm{Na}^{+}\right]$ratio reduced by two thirds compared with its ratio in sea water. This low sulphate content in winter snow is interpreted as the signature of frost flowers, which are formed on young sea ice when offshore winds predominate. Frost flowers have been described as the dominant source of sea salt to aerosol and precipitation in ice cores in coastal Antarctica but this is the first time their chemical signal has been described in the Arctic. The eastern summit does not show any frost flower signature and we interpret the unusually dynamic ice transport and rapid formation of thin ice on the Hinlopen Strait as the source of the frost flowers.
\end{abstract}

\section{Introduction}

Investigations focussing on the glaciology of Vestfonna glacier (Nordaustlandet, Svalbard) form a part of the IPYKinnvika project - an International Polar Year initiative

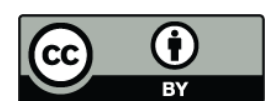

Correspondence to: E. Beaudon (ebeaudon@ulapland.fi) aimed at understanding the past, present and future environmental changes in the high Arctic. This study results from preliminary work carried out on Vestfonna ice cap in spring 2007.

Nordaustlandet is the northernmost island of Svalbard archipelago (Fig. 1). With an area of $2623 \mathrm{~km}^{2}$ (Schytt, 1964) and a maximum altitude of $622 \mathrm{~m}$ (Palosuo, 1987), Vestfonna is the second largest ice cap on Nordaustlandet, the adjacent Austfonna being the largest one. Like all the glaciers of Svalbard and almost everywhere in the Arctic (except on the highest part of Greenland), Vestfonna is subject to seasonal melting during most summers (nominally from June to September), though because of its maritime climate, sporadic melt can occur even during winter (here being nominally from December to March). The summer melting generally soaks a large part of the annual snow layer even though accumulation rates in Svalbard are relatively high compared to Greenland and other Arctic sites (Koerner, 1997).

The melt water percolation affects the temperature near the surface of the glacier and plays a major role in the firn/ice transition, which in Vestfonna occurs between 5 and $10 \mathrm{~m}$ depth (Watanabe et al., 2001). At this depth, the ice temperature is $-3.7^{\circ} \mathrm{C}$ (Kotlyakov et al., 2004). However, despite melt rates of $30-50 \%$ on another Svalbard glacier (Lomonosovfonna), isotopic variations (Pohjola et al., 2002) and chemical records (Moore et al., 2005) of climate are well preserved on annual or multi-year scales. Vestfonna winter surface snow contains a record of chemistry that has not been altered by melting and the ice cap has provided reliable climatic and environmental information (Watanabe et al., 2001; Matoba et al., 2002). Preliminary studies of snow are essential to interpret the ice core records, and snowpack

Published by Copernicus Publications on behalf of the European Geosciences Union. 
stratigraphy and chemistry can provide information on the annual accumulation rate at the drilling sites, the elution rates of chemical species, the formation mechanism of superimposed ice and other post-depositional phenomena.

Svalbard snow chemistry is also affected by anthropogenic pollution (Simões et al., 2001). In winter, Arctic haze from industrialized areas of Eurasia and North America (Barrie, 1986) can bring significant acidic and ammonium ions to the archipelago (Kekonen et al., 2005). For example Moore et al. (2006) calculated that the western European anthropogenic source represents 10 to $25 \%$ of the 20th century sulphate budget of Lomonosovfonna.

This article is based on the chemistry of snow pit samples from each end of the east-west summit ridge of the ice cap. Few chemical investigations have been conducted previously on Vestfonna (Schytt, 1964; Matoba et al., 2002). Earlier authors (e.g. Matoba et al., 2002) reported highly soluble ions (principally $\mathrm{NO}_{3}^{-}$and non sea-salt (nss) $\mathrm{SO}_{4}^{2-}$ ) concentrations in winter snow which they attributed to anthropogenic impurities advected with warm air masses coming from the south. This study concentrates on a particular layer of the winter snowpack with a high sea salt load that we propose to be of frost flower origin.

Frost flowers grow on a thin layer of supersaturated brine expelled from the refrozen surface of open leads (Rankin et al., 2002). Brine is drawn onto to the surface of frost crystals by capillary action, leading to large salinities in the frost flower. When sea ice surface temperatures are below $-8^{\circ} \mathrm{C}$, mirabilite $\left(\mathrm{Na}_{2} \mathrm{SO}_{4} \cdot 10 \mathrm{H}_{2} \mathrm{O}\right)$ starts to precipitate from the brine and is incorporated into the sea ice matrix. Because of this fractionation, the brine and, thus, the frost flowers are depleted in sodium and sulphate. Due to their fragile structure, frost flowers are easily windblown and redistributed to the snow surface. From Antarctic observations, Wolff et al. (2003) and Rankin et al. (2002) hypothesized that frost flowers constituted a significant source of sea-salt to the atmosphere and snow in winter. However, to our knowledge, the frost flower signature in the winter snow layer has never been described on an Arctic ice cap.

\section{Study site and methods}

Sampling locations were selected as part of a "pre-site" survey for a future deep drilling campaign. Therefore, preferences were given to flat and high elevated areas subject to minimal melting. Snow samples were collected from two pits located on the main summit ridge of Vestfonna ice cap in April-May 2007. Pit $1\left(79^{\circ} 59^{\prime} \mathrm{N}, 20^{\circ} 07^{\prime} \mathrm{E}, 622 \mathrm{~m}\right.$ a.s.l.) is close to the western summit which we term "Ahlmann" where snow studies and meteorological measurements were carried out during the IGY 1957. Pit 2 is close to the Japanese drilling site of $1995\left(79^{\circ} 58^{\prime} \mathrm{N}, 21^{\circ} 01^{\prime} \mathrm{E}, 600 \mathrm{~m}\right.$ a.s.l). Figure 1 shows the locations of the sampling sites.

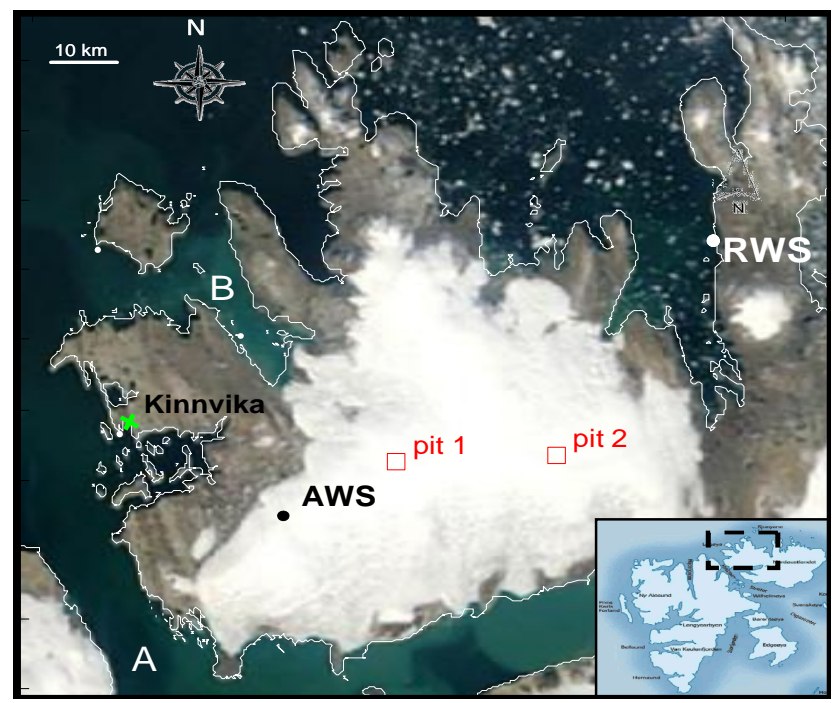

Fig. 1. Satellite image (image from NASA) of Western Nordaustlandet with location of Kinnvika station, snow-pit sampling sites (Pit 1 and Pit 2), Automatic Weather Station (AWS), Rijpfjorden Weather Station (RWS), Hinlopen strait (A) and Lady Franklinfjorden (B).

\subsection{Sampling}

The samples were taken in accordance with the ITASE (International Trans-Antarctic Scientific Expedition) protocol (Twickler and Whitlow, 1997). The sampling equipment was cleaned in the laboratory with ethanol and packed in polyethylene (PE) sealed bags prior to the fieldwork using a technique described by Kekonen et al. (2004). Disposable face masks, powder-free vinyl gloves and full-body clean suits were worn throughout on-site and off-site activities in order to minimize contamination during sampling, manipulations and analyses. The pits were dug as small trenches in the snowpack down to the visually located hard and icy layers of firn corresponding to the previous summer or warm autumn surface. Snow samples from Pit 1 were taken continuously in $5 \mathrm{~cm}$ increments down to a depth of $220 \mathrm{~cm}$ by pushing clean plastic cups into the side-wall of the trench. In Pit 2 (180 cm deep), $20 \mathrm{~cm}$ vertical snow cores were retrieved using a clean metallic cylinder and placed into double PE bags. In the presence of ice layers, a sharp clean stainlesssteel knife was used to cut sub-samples of $5 \mathrm{~cm}$. The snow cores were also weighed for density measurements. After retrieval, the samples were stored and transported in insulated boxes to the laboratory where they were kept frozen until analysis.

\subsection{Analyses}

Ten major water-soluble ions were measured with a Dionex DX-120 suppressed ion chromatograph, at the Finnish Forest Research Institute (Rovaniemi Unit). The anions 
a)

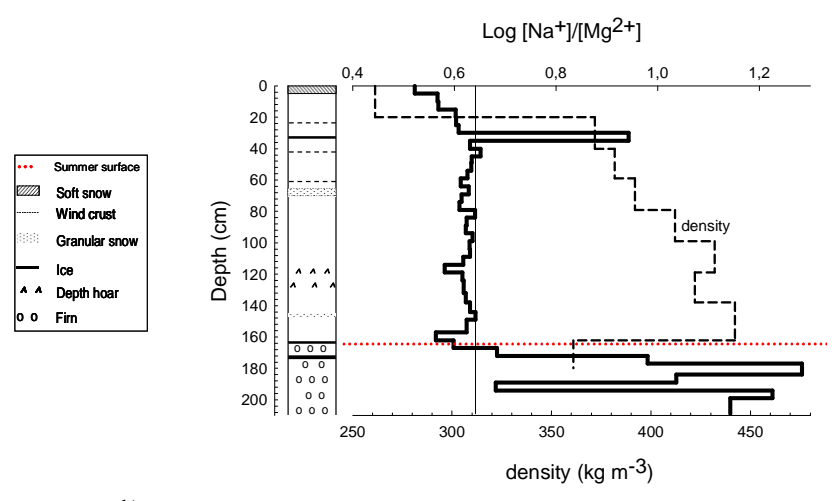

b)
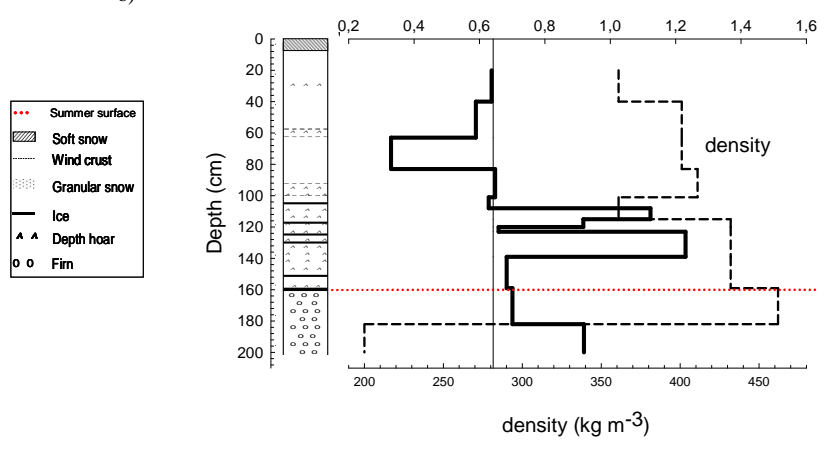

Fig. 2. Stratigraphy and depth profile of the melting indicator Log $\left[\mathrm{Na}^{+}\right] /\left[\mathrm{Mg}^{2+}\right]$ in $\mu \mathrm{Eql}^{-1}$ (solid line) and density (dashed line) for (a) Pit 1 and (b) Pit 2.The black arrow points the melting indicator value for Standard Mean Ocean (SMOW).

(methanesulfonate acid MSA, $\mathrm{Cl}^{-}, \mathrm{SO}_{4}^{2-}, \mathrm{NO}_{3}^{-}$) were determined using Dionex Ionpack AS15 columns. The cations $\left(\mathrm{Na}^{+}, \mathrm{NH}_{4}^{+}, \mathrm{K}^{+}, \mathrm{Mg}^{2+}, \mathrm{Ca}^{2+}\right)$ were determined using Dionex Ionpack CS12 columns. To minimize the effect of any systematic errors, samples were analyzed in a random depth order. The analytical method is described in detail by Virkkunen (2004). We estimate errors in ion measurements are $<5 \%$ based on repeat measurements and calibration against standards. The $\mathrm{nssSO}_{4}^{2-}$ and $\mathrm{nssCa}^{2+}$ fraction have been calculated using sodium as the reference species assuming that all observed sodium originates from sea-salt: $[\mathrm{nssX}]=[\mathrm{X}]-\mathrm{a}[\mathrm{Na}]$, where $\mathrm{X}$ is the fractionated species and $\mathrm{a}=[\mathrm{X}] /[\mathrm{Na}]$ in sea water.

\section{Results}

The samples of surface snow, i.e. the snow above the last summer layer, span the time period between the sampling time (April 2007) and the autumn of the previous year (2006). For each of the pits, Fig. 2 shows the stratigraphy and the vertical variance of snow density. $\log \left[\mathrm{Na}^{+}\right] /\left[\mathrm{Mg}^{2+}\right]$ ratio has been shown to be a good indicator of summer melting in Svalbard snow by Iizuka et al. (2002) and Grinsted et al. (2006).
In both sites, fresh snow, and wind packed snow layers, composed the upper parts of the sampling wall. At $35 \mathrm{~cm}$ depth in Pit 1, Log $\left[\mathrm{Na}^{+}\right] /\left[\mathrm{Mg}^{2+}\right]$ peaks and the stratigraphy shows an icy layer $0.5 \mathrm{~cm}$ thick. Below $120 \mathrm{~cm}$ in Pit 1 and below $130 \mathrm{~cm}$ in Pit 2 snow grains were coarser and depth-hoar layers were interleaved with thin ice layers $(0.5$ to $1 \mathrm{~cm}$ thick). In Pit 2, at the depth of these thin ice layers the value of the melt index, $\log \left[\mathrm{Na}^{+}\right] /\left[\mathrm{Mg}^{2+}\right]$, doubles. Below this section, a firn horizon with more frequently occurring melt ice layers was found from $160 \mathrm{~cm}$ to the bottom of the pits. The change in snow properties at $160 \mathrm{~cm}$ is accompanied by a rapid decline in density in both profiles. In Pit 1 the density drop is coupled with a doubling of the melt indicator $\log \left[\mathrm{Na}^{+}\right] /\left[\mathrm{Mg}^{2+}\right]$ (Fig. 2). We assume that this transition at the depth of $160 \mathrm{~cm}$ is the top of the 2006 summer layer. Based on the mean density of snow between $0-160 \mathrm{~cm}$, we found that the accumulation rate was approximately $0.62 \mathrm{~m} w . e . y r^{-1}$ at Pit 1 and $0.64 \mathrm{mw}^{2}$.e. $\mathrm{yr}^{-1}$ at Pit 2. These estimates are similar to the $0.595{\mathrm{~m} \mathrm{w} . e . \mathrm{yr}^{-1} \text { found }}^{-1}$ during the IGY expeditions (Schytt, 1964).

Mean concentrations of the ionic species and the calculated $\mathrm{nssCa}^{2+}$ and $\mathrm{nssSO}_{4}^{2-}$, standard deviations $(\sigma)$ and the coefficient of variation $(\mathrm{CV}=\sigma / \bar{x})$ are presented in Table 1 for both pits. The concentrations of major ions $\left(\mathrm{Cl}^{-}, \mathrm{SO}_{4}^{2-}\right.$, $\mathrm{Na}^{+}, \mathrm{Ca}^{2+}, \mathrm{Mg}^{2+}, \mathrm{K}^{+}$) range from 1.84 to $84 \mu \mathrm{Eql}^{-1}$ in Pit 1 and from 0.37 to $17.3 \mu \mathrm{Eql}^{-1}$ in Pit 2 .

The concentration profiles for the cations and anions in the two pits are shown in Fig. 3. In the case of Pit 1, there is a concentration peak present at about $100 \mathrm{~cm}$ for $\mathrm{Na}^{+}, \mathrm{K}^{+}$, $\mathrm{Mg}^{2+}, \mathrm{Ca}^{2+}, \mathrm{Cl}^{-}$and $\mathrm{SO}_{4}^{2-}$. This snow layer between $95 \mathrm{~cm}$ and $115 \mathrm{~cm}$ presents ionic concentrations (except nitrate and MSA) from 4 to 6 times higher than the mean concentration for the snowpack above and below (excluding the firn layer starting at $160 \mathrm{~cm}$ ). The absence of a peak in nitrate, which is eluted more easily than other ions, indicates that ions in this layer were not introduced by melting of layers above, such as the thin melt layer at $35 \mathrm{~cm}$ depth. Furthermore, the calculated concentration of $\mathrm{nssSO}_{4}^{2-}$ (Fig. 3) in this layer was found to be clearly negative. This means that in this layer sulphate ions do not have an anthropogenic or terrestrial source, but must be marine in origin. Pit 2 displays a regular decrease in ionic concentrations from the surface of the pit to the summer snow surface with the exception of a small peak between $85 \mathrm{~cm}$ and $105 \mathrm{~cm}$.

\section{Discussion}

A comparison of the snowpack ionic budgets between the sites (Table 1) reveals that Pit 1 has systematically higher concentrations than Pit 2 which probably represents a geographical trend across the ice cap. The major sources of these ions are marine (Matoba et al., 2002) and there is no topographical divide between the two sites. This indicates a variable geographical distribution of major marine ions on 
Table 1. Mean concentrations $(\bar{x})$, standard deviations $(\sigma)$ in $\mu \mathrm{Eql}^{-1}$ and coefficients of variation, $\mathrm{CV}$, in the entire surface snowpack of Pit 1 and Pit 2 and for the Frost Flower layer in Pit 1 (FF).

\begin{tabular}{lccccccccc}
\hline & \multicolumn{3}{c}{ Pit 1 (n=39) } & \multicolumn{3}{c}{$\mathrm{FF}(n=5)$} & \multicolumn{3}{c}{ Pit 2(n=12) } \\
& $\bar{x}$ & $\sigma$ & $\mathrm{CV}$ & $\bar{x}$ & $\sigma$ & $\mathrm{CV}$ & $\bar{x}$ & $\sigma$ & $\mathrm{CV}$ \\
\hline $\mathrm{MSA}$ & 0.03 & 0.06 & 1.87 & 0.01 & 0.03 & 2.11 & 0.01 & 0.02 & 2.04 \\
$\mathrm{Cl}^{-}$ & 64.68 & 66.32 & 1.03 & 208.39 & 73.22 & 0.35 & 16.72 & 18.51 & 1.11 \\
$\mathrm{SO}_{4}^{2-}$ & 8.59 & 7.92 & 0.92 & 25.46 & 7.06 & 0.28 & 2.44 & 2.47 & 1.01 \\
$\mathrm{NO}^{3-}$ & 0.61 & 0.53 & 0.88 & 0.70 & 0.35 & 0.50 & 0.27 & 0.29 & 1.08 \\
$\mathrm{Na}^{+}$ & 75.15 & 85.83 & 1.14 & 262.57 & 103.02 & 0.39 & 17.30 & 18.94 & 1.09 \\
$\mathrm{NH}^{4+}$ & 0.75 & 0.42 & 0.56 & 0.67 & 0.62 & 0.93 & 1.14 & 0.56 & 0.49 \\
$\mathrm{~K}^{+}$ & 1.65 & 1.94 & 1.17 & 5.88 & 2.34 & 0.40 & 0.38 & 0.40 & 1.08 \\
$\mathrm{Mg}^{2+}$ & 17.46 & 20.25 & 1.16 & 61.69 & 23.78 & 0.39 & 4.15 & 4.81 & 1.16 \\
$\mathrm{Ca}^{2+}$ & 3.56 & 3.82 & 1.07 & 11.97 & 4.67 & 0.39 & 2.55 & 1.76 & 0.69 \\
$\mathrm{nssCa}^{2+}$ & 0.25 & 0.43 & 1.69 & 0.41 & 0.76 & 1.88 & 1.79 & 1.33 & 0.74 \\
$\mathrm{nssSO}_{4}^{2-}$ & -0.46 & 3.33 & -7.20 & -6.19 & 5.47 & -0.88 & 0.36 & 0.51 & 1.42 \\
\hline
\end{tabular}

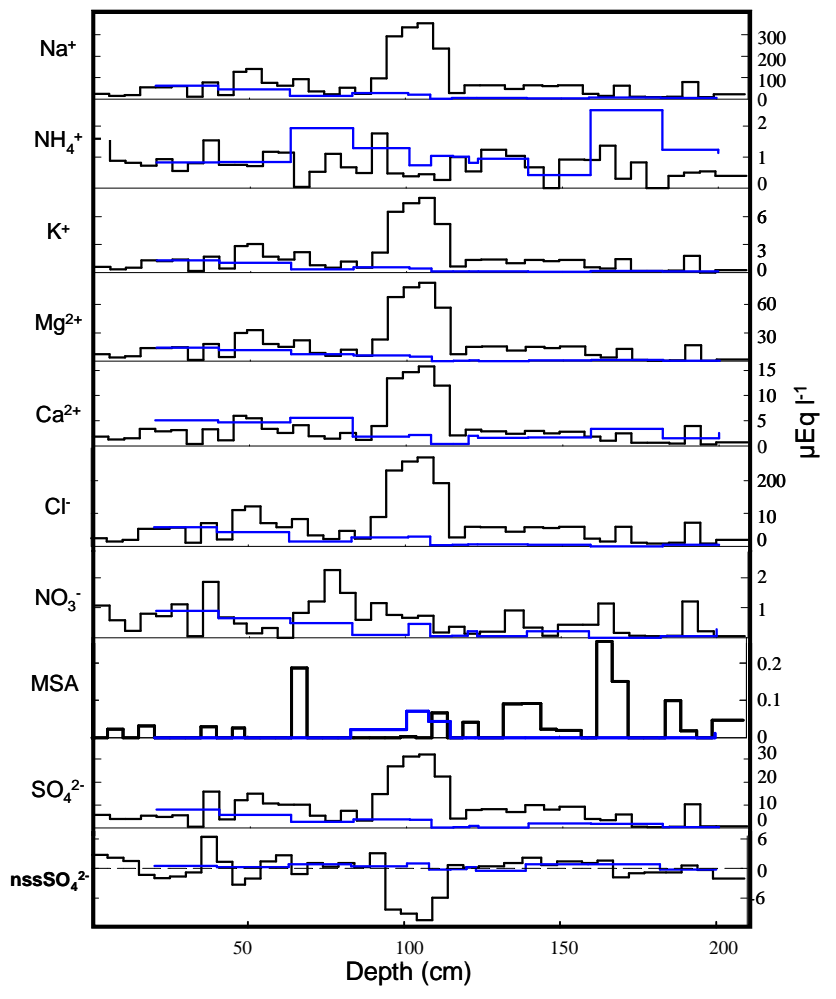

Fig. 3. Ion concentration $\left(\mu \mathrm{Eq} 1^{-1}\right)$ in Pit1 (black histogram) and Pit 2 (blue histogram).

Vestfonna, with summit Ahlmann under stronger marine influence. In addition, the lower $\mathrm{nssSO}_{4}^{2-}$ and $\mathrm{nssCa}^{2+}$ contents observed in Pit 1 also point towards higher oceanic inputs at Pit 1 compared to Pit 2. The snow stratigraphy and densities also support the chemical melt indicator in suggesting that the snow layer at the depth of $1 \mathrm{~m}$ in Pit 1 has not experienced melting.
Table 2. Weight ratios of ions in Halley station Frost Flowers, Antarctica (HFF), Frost Flowers Layer (FFL) and bulk sea water (SMOW).

\begin{tabular}{lccccc}
\hline & $\mathrm{K} / \mathrm{Na}$ & $\mathrm{Mg} / \mathrm{Na}$ & $\mathrm{Ca} / \mathrm{Na}$ & $\mathrm{Cl} / \mathrm{Na}$ & $\mathrm{SO}_{4} / \mathrm{Na}$ \\
\hline HFF & 0.0389 & 0.1400 & 0.0441 & 2.0400 & 0.0853 \\
FFL & 0.0220 & 0.2360 & 0.0452 & 0.8120 & 0.0920 \\
SMOW & 0.0370 & 0.1200 & 0.0382 & 1.7900 & 0.2520 \\
\hline
\end{tabular}

\subsection{Frost flowers as a source of fractionated sea-salt in winter}

At Antarctic coastal sites, high sea-salt concentrations and strong nssSO ${ }_{4}^{2-}$ depletion found in winter snow have been described as evidence of an important sea ice surface source (Rankin et al, 2002). Other studies of Antarctic winter snow (e.g. Hall and Wolff, 1998) confirm that air coming from fresh sea ice covered with frost flowers has a high salinity and a negative $\mathrm{nsSSO}_{4}^{2-}$ signal. Based on the similar chemical characteristics found in the highly saline layer in Pit 1 winter snow, we propose these features represent a frost flower chemical fingerprint. Additionally, the sulphate to sodium ratio $\left(\mathrm{SO}_{4}^{2-} / \mathrm{Na}^{+}\right)$in this particular layer of the winter snowpack, 0.092, is about one third that of sea water $(0.25)$ and very close to the $\mathrm{SO}_{4}^{2-} / \mathrm{Na}^{+}$ratio measured by Rankin et al. (2002) in Antarctic frost flowers (0.085) and winter aerosols (0.1).

Earlier investigations on Vestfonna snow (Matoba et al, 2002) showed that peaks of $\delta^{18} \mathrm{O}_{,} \mathrm{Na}^{+}, \mathrm{Cl}^{-}$in winter snow were caused by advection of warm air masses with a high content of sea-salt. These winter warm events were also associated with high $\mathrm{NO}_{3}^{-}, \mathrm{NH}_{4}^{+}$and nssSO $\mathrm{S}_{4}^{2-}$ peaks and the authors concluded in favour of both anthropogenic and sea water sources. The concentrations of $\mathrm{NO}_{3}^{-}$and $\mathrm{NH}_{4}^{+}$do 


\section{AWS Vestfonna}

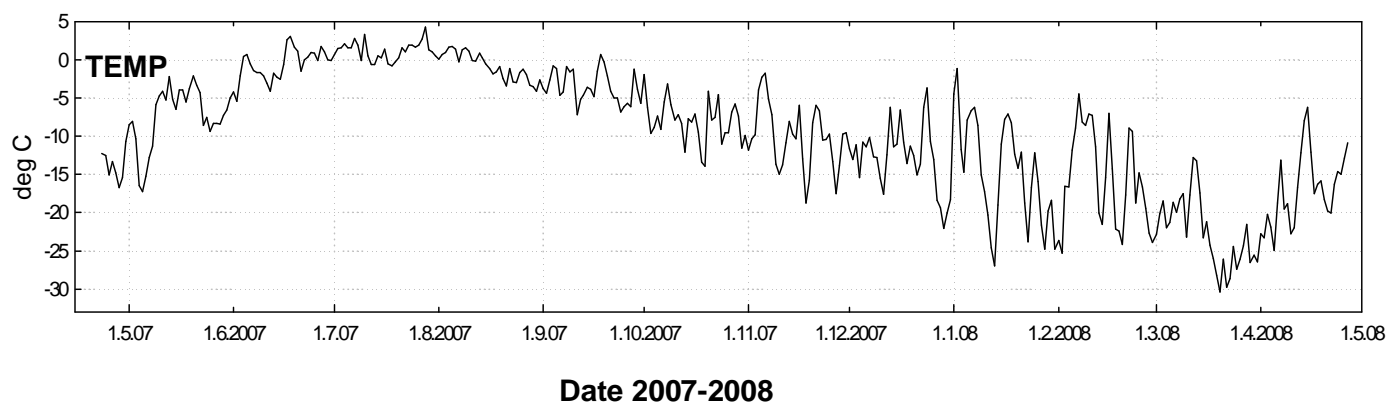

Fig. 4. Temperature $\left({ }^{\circ} \mathrm{C}\right)$ plotted from AWS (Personal communication from Regine Hock \& Ulf Jonsell 2008).

not exhibit peaks and $\mathrm{nssSO}_{4}$ is clearly negative (Fig. 3) in the frost flower layer. We can therefore exclude anthropogenic contribution to the sulphate. In addition, the $\mathrm{Mg} / \mathrm{Na}(0.236)$ and $\mathrm{Ca} / \mathrm{Na}(0.045)$ weight ratios in the frost flower layer are slightly higher than those in bulk sea water (SMOW, Standard Mean Ocean Water) (0.12 and 0.038, respectively, Table 2), implying that sea-salt aerosols incorporated into the winter snow are depleted also in sodium. This is to be expected if we assume that the depletion of both sodium and sulphate is due to crystallization of mirabilite $\left(\mathrm{Na}_{2} \mathrm{SO}_{4} \cdot 10 \mathrm{H}_{2} \mathrm{O}\right)$ from sea water at temperatures below $-8.2^{\circ} \mathrm{C}$. Simulations of sea water freezing along the Gitterman pathway by Marion et al. (1999) reveal that mirabilite is the only salt to precipitate out when sea ice is formed between $-8.2^{\circ} \mathrm{C}$ and $-22^{\circ} \mathrm{C}$. Colder ice surfaces are generally associated with multiyear ice on which frost flowers do not form. The ions deposited in the frost flower layer clearly display a fractionated sea-salt signature and we can conclude that sodium is the cation depleted with sulphate.

According to Rankin et al. (2002) sodium and sulphate depletion due to mirabilite precipitation are expected in glacier snow if this snow has been affected by a frost flower wind deposition. Frost flowers grow on patches of thin slush layers on young sea-ice formed in leads of open water. To create these leads, appropriate meteorological conditions in terms of wind speed and direction are necessary and must be combined with sufficiently low temperatures (below $-8^{\circ} \mathrm{C}$ ) to allow fractionation to occur. Such cold temperatures are frequently reached during the winter in Nordaustlandet (Fig. 4). Once offshore winds open up a coastal lead, new sea ice is produced. Then, the wind direction must change to blow onshore in order to carry the aerosols derived from the frost flowers inland. Hall and Wolff (1998) show that strong winds are not associated with frost flower signatures perhaps because strong winds destroy the flower's fragile crystals and the thin surface skim of brine on which they form. So moderate winds and low temperatures are needed.

Patches of enriched brine on solid ice create an irregular surface with a greater roughness and backscatter coeffi- cient at radar frequencies than ice without flowers. A synthetic aperture radar (SAR, carried by the ERS-1 satellite), which is sensitive to the nature of sea ice surface, has been used to identify leads covered by frost flowers in the Arctic (Melling, 1998; Ulander et al., 1995). In addition, a radar study conducted in Svalbard archipelago using the ERS-2 satellite in March-April 1998 (Augstein, 2000) registered strong reflectance of a $15 \times 15 \mathrm{~km}^{2}$ area of the Arctic Ocean west of Nordaustlandet $\left(80^{\circ} 42^{\prime} \mathrm{N}, 8^{\circ} \mathrm{E}\right)$, which was interpreted as frost flowers by Kaleschke et al. (2004). These observations support our assumption that frost flowers can form around Nordaustlandet and constitute a potential source of fractionated aerosols for Svalbard winter snow.

Moreover, the snow layer affected by the frost flower peak is too thick $(20 \mathrm{~cm})$ to be formed by fog, which is also unsupported by the stratigraphy (Fig. 2). The importance of fog deposits (rime, hoar frost) has been overestimated in Nordaustlandet during the past; Schytt (1964) observed that the snow mass contributed by fog deposits amounts to roughly 3 percent of the total accumulation.

\subsection{Hinlopen Strait: newly formed sea ice in winter}

To locate the young winter sea ice formation area, we used the records from the weather station installed on the eastern coast of Rijpfjorden $\left(80^{\circ} 13^{\prime} \mathrm{N}, 22^{\circ} 31^{\prime} \mathrm{E}\right.$ ) (see Fig. 1 for location). The wind data for the period 2007-2008 are plotted in Fig. 5. Two predominant wind directions are observed: one is 290 to $340^{\circ}$ (from the Arctic Ocean, NW) and the other is 110 to $135^{\circ}$ (from Austfonna ice cap, SE). These wind directions are consistent with the dominant regional easterly winds (Niedzwiedz, 1997; Dagestad et al., 2006) and with our field observations in spring 2007 and 2008 at summit Ahlmann where strong winds came most of the time from the Arctic Ocean channeled by Lady Franklinfjorden (Fig. 1). This suggests that the Arctic Ocean is not the frost flowers source area, since the frost flowers signature is not a continuous signal in the snow pack, but an infrequent event. The only plausible source is Hinlopen Strait (SSW). 


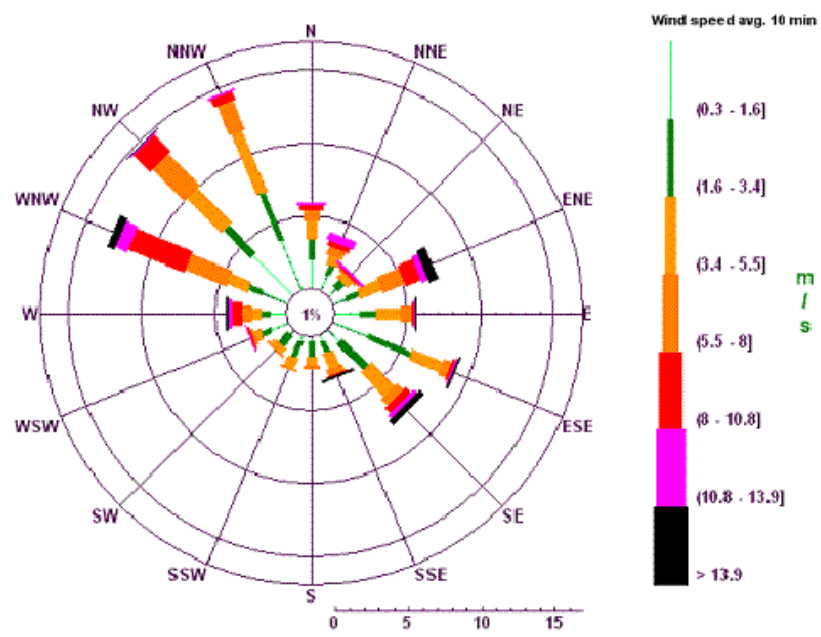

Fig. 5. Rose diagram showing wind direction (deg.) and speed (m/s) from August 2007 to August 2008 at Rijpfjorden Weather Station (source: http://158.39.11.101/command=RTMC $\backslash \&$ screen= WindYear\%20\%20).

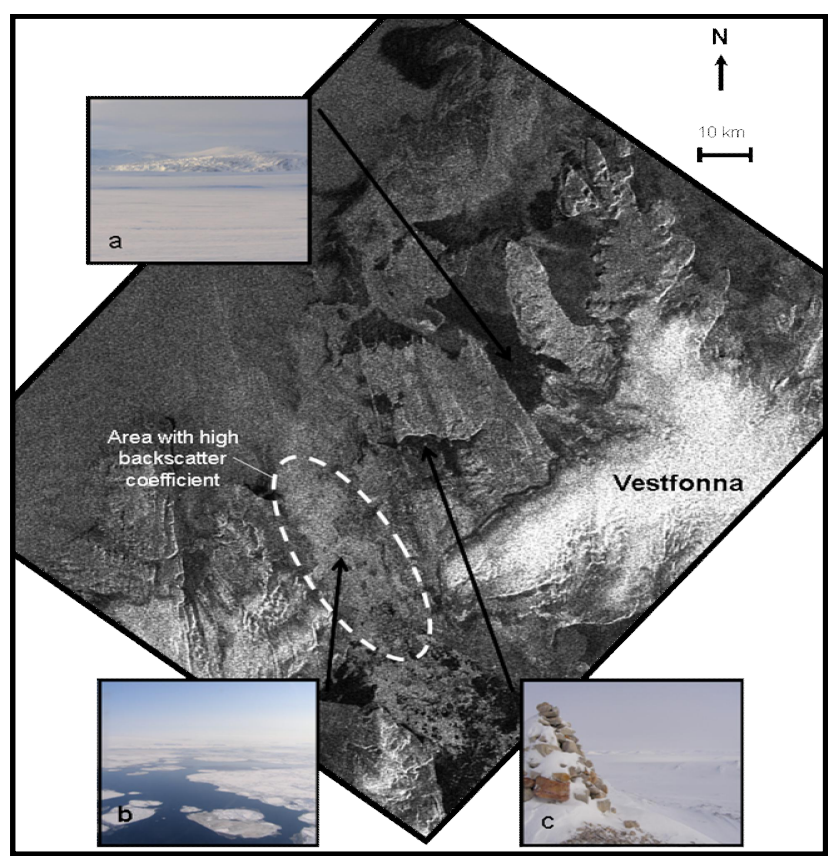

Fig. 6. ERS-2 SAR image of Hinlopen Strait and the western part of Nordaustlandet on 22 February 2007 compared with ground shots of (a) Lady Franklinfjorden (4th May 2007), (b) Hinlopen (19th April 2007), and (c) Murchinson Bay (5th May 2007) taken during the field campaign in spring 2007 (Source SAR image: ESA).

During the field campaigns we noted that Hinlopen Strait was partially covered with a thin slick of ice and partially ice free, whereas Lady Franklinfjorden was completely frozen. These observations from early spring corroborate those made by the satellite ERS-2 in February 2007: SAR images show a
Table 3. Concentration $\left(\mu \mathrm{Eql}^{-1}\right)$ of ions in Halley station Frost Flowers, Antarctica (HFF), Frost Flowers Layer (FFL) and Bulk Sea water (SMOW).

\begin{tabular}{lcccccc}
\hline & $\mathrm{Na}$ & $\mathrm{K}$ & $\mathrm{Mg}$ & $\mathrm{Ca}$ & $\mathrm{Cl}$ & $\mathrm{SO}_{4}$ \\
\hline HFF & 154 & 4 & 41 & 8 & 207 & 6 \\
FFL & 263 & 6 & 62 & 12 & 208 & 25 \\
SMOW & 468 & 10 & 107 & 21 & 553 & 56 \\
\hline
\end{tabular}

much higher backscatter coefficient in Hinlopen than in Lady Franklinfjorden or Murchinson Bay (Fig. 6). Strong currents in the Hinlopen Strait continuously create exposed areas of sea water which freeze rapidly in the winter and create areas of local, freshly formed ice with a surface cover of concentrated brine. Moreover, the decrease in sea-salt concentrations with distance across the ice cap (at Pit 2), indicates that the sea-salt source is closer to Pit 1 than to Pit 2. From these observations we can speculate that the principal source of saline air masses is most likely Hinlopen Strait (about $45 \mathrm{~km}$ from Pit 1 and about $60 \mathrm{~km}$ from Pit 2). Unlike in Pit 1, melting layers are present in the winter snowpack of Pit 2 while the frost flower chemical signature is absent in the pack. This shows evidence of locally variable atmospheric conditions at the two summits which are $20 \mathrm{~km}$ apart. We frequently experienced this local weather variability during our two field campaigns in 2007 and 2008 when snow was sometimes observed at one pit site but not the other.

\subsection{Fractionated salt as a new sea ice production proxy}

Wolff et al., 2003 have suggested that sea-salt concentrations in ice cores can be used to infer aspects of the marine environment in the past. Generally, such studies have assumed that the atmospheric sea-salt concentrations are related to a combination of sea ice extent and wind speed. Although Svalbard ice cores suffer from postdepositional percolation they have been proven to give reliable paleoinformation (Kekonen et al., 2005; Grinsted et al., 2006; Moore et al., 2009). Iizuka et al. (2002) successfully extracted information on environmental changes from chemical signals in a Nordaustlandet ice core. Also, Watanabe et al. (2001) reported that most of the chemical features contained in the initial snow of Austfonna still remained in the ice core. We could therefore expect that the preservation of the frost flower chemical signature in Vestfonna ice is possible. If the signal described in this paper is not disrupted by melt percolation, it might serve as a potential proxy for sea ice production (extent) in winter via the reconstruction of past atmospheric conditions. Additionally, if higher seasalt levels measured in winter snow are systematically associated with moderate winds (and not strong winds), we could attribute high sea-salt concentrations (Table 3) seen in cold periods, such as the Little Ice Age, in coastal or maritime ice 
cores to changes in sea ice production, rather than increased storminess and more efficient transport.

The apparent rarity of the frost flower signature in Arctic regions may be related to the quite different sea ice conditions in the Arctic Ocean compared with the seas surrounding Antarctica. Multi-year floes tend to be more common in the Arctic basin, while in the Southern Ocean the pack ice reforms each year, so there is more young and thin ice that provides suitable frost flower sites around Antarctica than in much of the Arctic. The Arctic is also much more affected by anthropogenic and terrestrial $\mathrm{SO}_{4}^{2-}$ input than Antarctica and large $\mathrm{nsSOO}_{4}^{2-}$ are typical. This would tend to disguise the characteristic $\mathrm{SO}_{4}^{2-} / \mathrm{Na}^{+}$frost flower signature.

\section{Conclusion}

By comparing chemical analyses of the snowpack from two snow pits in Vestfonna ice cap, we show that the western side of Vestfonna receives a greater marine ionic contribution than the eastern edge, and that the winter snowpack at the western end (summit Ahlmann) is enriched in sea-salt fractionated in sodium and sulphate. As the particular nature of this saline content corresponds to a typical frost flower signature described in aerosols and snow from Antarctic coastal regions, we hypothesize that frost flowers, possibly formed in Hinlopen Strait, could form a significant source of seasalt in winter snow in Vestfonna. However, to rigorously assess the reliability of the frost flower chemical signature as a proxy for winter sea ice production around Nordaustlandet, the annual snowpack needs to be analyzed at different locations on Vestfonna and more snow pit studies carried out along with continuous meteorological measurements should be performed. Studies of shallow ice cores drilled at the two summits and new snow analyses are currently underway. Frost flowers chemical signatures have not yet been reported at other locations in the Arctic. However, their detection in ice cores from areas that, at present, are usually surrounded by multi-year pack ice could indicate that, in earlier periods, young sea ice was present instead.

Acknowledgements. We thank the Finnish Forest Research Institute, Rovaniemi Research Unit for the use of cold-room and clean-room facilities. Financial support was provided by the Finnish Academy. We are grateful to Veijo Pohjola and Ulf Jonsell for their important assistance in the field. We also thank Regine Hock who provided the meteorological data from the AWS on Vestfonna.

Edited by: J. L. Bamber

\section{References}

Augstein, E.: Final report on the Arctic Radiation and Turbulence Interaction Study (ARTIST). Bremerhaven, Alfred-WegenerInstitut für Polar und Meeresforschung, 92-105, 2000.

Barrie, L. A.: Arctic air chemistry: an overview, edited by: Stonehouse, B., Arctic air pollution, Cambridge, Cambridge University Press, 5-23, 1986.

Dagestad, K. F., Johannessen, J. Hauge, G., Kerbaol, V., et al.: High-resolution Wind Field Retrievals off the Norwegian Coast: Comparing ASAR Observations and MM5 Simulations. Proceedings OceanSAR 2006 St. John's, NL, Canada, 2006.

Drinkwater, M. R. and Crocker, G. B.: Modeling changes in the dielectric and scattering properties of young snow-covered sea ice at GHz frequencies, J. Glaciol., 34, 274-282, 1988.

Grinsted, A., Moore, J. C., Pohjola, V., Martma, T., et al.: Svalbard summer melting, continentality and sea ice extent from the Lomonosovfonna ice core, J. Geophys. Res., 111, D07110, 10.1029/2005JD006494, 2006.

Hall, J. S. and Wolff, E. W.: Causes of seasonal and daily variations in aerosol sea-salt concentrations at a coastal Antarctic station, Atmos. Environ., 32, 3669-3677, 1998.

Iizuka, Y., Igarashi, M., Kamiyama, K., Motoyama, H., et al.: Ratios of $\mathrm{Mg}^{2+} / \mathrm{Na}^{+}$in snowpack and an ice core at Austfonna ice cap, Svalbard, as an indicator of seasonal melting, J. Glaciol., 48(162), 452-460, 2002.

Kaleschke, L. and Heygster, G.: Towards multisensory microwave remote sensing of frost flowers on sea ice, Ann. Glaciol., 39, 219-222, 2004.

Kekonen, T., Perämäki, P., Moore, J. C., et al.: Comparison of analytical results for chloride, sulphate and nitrate obtained from adjacent ice core samples by two ion chromatographic methods, J. Environ. Monitor., 6, 147-152, 2004.

Kekonen, T., Moore, J. C., Perämäki, P., et al.: The 800 year long ion record from the Lomonosovfonna (Svalbard) ice core, J. Geophys. Res., 110, DO7304, doi:1029/2004JD005223, 2005.

Koerner, R. M.: Some comments on climatic reconstructions from ice-cores drilled in areas of high melt, J. Glaciol., 43(143), 9097, 1997.

Kotlyakov, V. M., Arkhipov, S. M., Henderson, K. A., et al.: Deep drilling of glaciers in Eurasian Arctic as a source of paleoclimatic records, Quatern. Sci. Rev., 23, 1371-1390, 2004.

Marion, G., Farren, M. R. E., Komrowski, A. J., et al.: Alternative pathways for seawater freezing, Cold Reg. Sci. Technol., 29, 259-266, 1999.

Matoba, S., Narita, H., Motoyama, H., et al.: Ice core chemistry of Vestfonna Ice Cap in Svalbard, Norway, J. Geophys. Res., 107(D23), 4721, doi:10.1029/2002JD002205, 2002.

Melling, H.: Detection of features in first-year pack ice by synthetic aperture radar, Int. J. Remote Sens., 19(6), 1223-1249, 1998.

Moore, J. C., Grinsted, A., Kekonen, T., and Pohjola, V.: Separation of melting and environmental signals in an ice core with seasonal melt, Geophys. Res. Lett., 32, L10501, doi:10.1029/2005GL023039, 2005.

Moore, J. C., Kekonen, T., Grinsted, A., et al.: Sulfate source inventories from a Svalbard ice core record spanning the Industrial Revolution, J. Geophys. Res., 111, D15307, doi:10.1029/2005JD006453, 2006.

Moore, J. C. and Grinsted, A.: Ion fractionation and percolation in ice cores with seasonal melting, Physics of Ice Core Records 
II, edited by: Hondoh, T., Hokkaido University Press, in press, 2009.

Niedzwiedz, T.: Czastoea wystapowania typw cyrkulacji nad Spitsbergen (1951-1995), [Frequency of circulation patterns above Spitsbergen (1951-1995)], Probl. Klimatol. Polarnerj, 7, 9-16, 1997.

Palosuo, E.: A Study of Snow and Ice Temperatures on Vestfonna, Svalbard, 1956, 1957 and 1958, Geogr. Ann. A, 69A(3/4), 431437, 1987.

Pohjola, V. A., Moore, J. C., Isaksson, E., Jauhiainen, T., van de Wal, R. S. W., Martma, T., Meijer, H. A. J., and Vaikmäe, R.: Effect of periodic melting on geochemical and isotopic signals in an ice core from Lomonosovfonna, Svalbard, J. Geophys. Res., 107(D4), 4036, doi:10.1029/2000JD000149, 2002.

Rankin, A. M., Wolff, E. W., Auld, V., et al.: Frost Flowers as a source of fractionated sea salt aerosol in the polar regions, Geophys. Res. Lett., 27, 3469-3472, 2000.

Rankin, A. M., Wolff, E. W., Martin, S., et al.: Frost flowers: implications for tropospheric chemistry and ice core interpretation, J. Geophys. Res., 107(D23), 4683, doi:0.1029/2002JD002492, 2002.

Schytt, V.: Scientific Results of the Swedish Glaciological Expedition to Nordaustlandet, Spitsbergen, 1957 and 1958, Geografiska Annaler, 46(3), 242-281, 1964.

Simões, J. C. and Zagorodnov, V. S.: The record of anthropogenic pollution in snow and ice in Svalbard, Norway, Atmos. Environ., 35, 403-413, 2001.
Twickler, M. and Whitlow, S.: Appendix B, in: Guide for the collection and analysis of ITASE snow and firn samples, edited by: Mayewski, P. A. and Goodwin, I. D., International TransAntarctic Scientific Expedition (ITASE), Bern, Switzerland, Past Global Changes (PAGES report 97-1), 1997.

Ulander, L. M. H., Carlstrom, A., Askne, J., et al.: Effect of frost flowers rough saline snow and slush on the ERS-1 SAR backscatter of thin arctic sea ice, Int. J. Remote Sens., 16(17), 3287-3305, 1995.

Virkkunen, K.: Snow pit studies in 2001-2002 in Lomonosovfonna, Svalbard, MSc thesis, Univ. of Oulu, Finland, 26-34, 2004.

Virkkunen, K., Moore, J. C., Isaksson, E., et al.: Warm summers and ion concentrations in snow: present day and Medieval Warm Period comparisons from snow pits and an ice core from Lomonosovfonna, Svalbard, J. Glaciol., 53(183), 623-634, 2007.

Watanabe, O., Motoyama, H., Igarashi, M., et al.: Studies on climatic and environmental changes during the last few hundred years using ice-cores from various sites in Nordaustlandet, Svalbard, Nat. Inst. Polar Res. Mem., 54 (special issue), 227-242, 2001.

Wolff, E. W., Rankin, A. M., and Rothlisberger, R.: An ice core indicator of sea ice production?, Geophys. Res. Lett., 30(22), 2158, doi:10.1029/2003GL018454, 2003. 